\title{
Dependence of thyroxine utilization rate on dietary composition
}

\author{
BY D. L. INGRAM AND S. E. EVANS \\ ARC Institute of Animal Physiology, Babraham, Cambridge, and \\ Department of Clinical Chemistry, Queen Elizabeth Medical Centre, \\ Edgbaston, Birmingham
}

(Received I7 August 1979 - Accepted I9 December 1979)

I. The rate of utilization $(k)$ of labelled thyroxine increased when energy intake, given as standard pig meal, was doubled from 20 to $40 \mathrm{~g} / \mathrm{kg}$ body-weight per $\mathrm{d}$. When the bulk of food was increased, but not its energy content, the value of $k$ did not change. Ambient temperature was constant throughout the experiment.

2. Groups of pigs were given pig meal at $20 \mathrm{~g} / \mathrm{kg}$ body-weight, $40 \mathrm{~g} / \mathrm{kg}$ body-weight or $20 \mathrm{~g} / \mathrm{kg}$ body-weight plus a supplement. The supplement was of equivalent energy content to $20 \mathrm{~g} \mathrm{pig} \mathrm{meal} / \mathrm{kg}$ body-weight and consisted of coconut (high-fat), fish meal (high-protein) or glucose. The values of $k$ were similar on diets $(\mathrm{g} / \mathrm{kg}$ body-weight) of $40 \mathrm{pig}$ meal, $20 \mathrm{pig}$ meal plus coconut, and 20 pig meal plus fish meal. When the supplement was glucose however the values of $k$ were similar to that for $20 \mathrm{~g} \mathrm{pig} \mathrm{meal} / \mathrm{kg} \mathrm{body-weight.}$

3. The plasma concentrations of $\mathrm{T}_{4}$, and triiodothyronine were not affected by eating a meal, or by changing the energy intake presented as pig meal. A comparison between pigs given $20 \mathrm{~g} \mathrm{pig} \mathrm{meal} / \mathrm{kg}$ body-weight plus supplements of bran, coconut, fish meal or glucose revealed differences in the concentration of both hormones. When food was withdrawn for $5 \mathrm{~d}$ the concentrations of both hormones declined.

A major factor influencing the rate of secretion and utilization of thyroid hormones in animals is a change in ambient temperature (Freinkel \& Lewis, 1957; Reichlin, I966). It has been demonstrated that an increase in heat loss from an animal is followed by the release of thyroid-stimulating hormone and a subsequent increase in the secretion of thyroxine $\left(\mathrm{T}_{4}\right)$, (Hershman et al. 1970; Reichlin et al. 1972). Exposure to a cold ambient temperature, however, is usually accompanied by an increase in food intake. Evans \& Ingram (1977) found that although exposure to cold initiated an increase in the secretion of $T_{4}$, the rate of utilization of $T_{4}$ remained unchanged unless food intake was increased. Subsequently Ingram \& Kaciuba-Uscilko (1977) reported that, in growing pigs, changes as great as those associated with the combination of a fall in ambient temperature and an increase in energy intake, could be elicited by a similar increase in energy intake alone.

The next steps were to determine: ( $\mathrm{I}$ ) whether the stimulus to an increased rate of use of $\mathrm{T}_{4}$ was a simple increase in energy intake, or if the quantity of specific nutrients needed to be increased; (2) whether the change in the rate of use of $T_{4}$ associated with an increase in energy intake was accompanied by a change in the plasma levels of $T_{4}$ and triiodothyronine $\left(\mathrm{T}_{3}\right)$. In the present study these points have been investigated in young, immature pigs. $A$ preliminary communication of part of these results has been presented (Ingram \& Dauncey, I980).

\section{MATERIALS AND METHODS}

Animals

Sixty-eight pigs of the Large White breed aged between 2 and 3 months were used.

\section{Housing}

Each pig was housed separately in a cage at a controlled environmental temperature of $25^{\circ}$ with continuous lighting. 
Table I. Composition of foods $(\mathrm{g} / \mathrm{kg})$ and supplements given to pigs

\begin{tabular}{lccrr} 
& & \multicolumn{3}{c}{ Available nutrients } \\
Food & Gross Energy (kJ) & Protein & Fat & Carbohydrate \\
Pig meal & 15800 & 180 & 20 & 620 \\
Coconut & 28500 & 60 & 620 & 60 \\
Fish meal & 17900 & 660 & 60 & 0 \\
Glucose & 15600 & 0 & 0 & 1000 \\
Bran* & 8720 & 140 & 60 & 270 \\
& * Bran remains mostly undigested in the pig. & &
\end{tabular}

\section{Feeding and diet}

The pigs were fed once daily between 08.00 and 10.00 hours. Water was provided ad lib. The amount of food given was related to the animal's body-weight and varied between 10 and $60 \mathrm{~g} / \mathrm{kg}$ body-weight according to the experiment. Under normal husbandry conditions pigs are fed at a rate of 40 or $45 \mathrm{~g} / \mathrm{kg}$ body-weight. The standard diet consisted of a commerciallyavailable pig meal, and in addition some animals were given a supplement of bran, fish meal, desiccated coconut, or glucose. The compositions of all foods as derived from food tables (Paul \& Southgate, 1978) or maker's analysis are given in Table I.

\section{Surgery}

All pigs had a catheter inserted into the jugular vein. The catheter which was led under the skin and emerged between the shoulder blades, was plugged, coiled and kept in a pouch on the pig's back. Operations were carried out under general anaesthetic and sterile conditions 4 to $5 \mathrm{~d}$ before the experiment began.

\section{Blood samples}

Samples of blood were taken while the pigs were in their normal cages. The blood was placed in a heparinized tube, mixed and the plasma separated by centrifugation. The plasma concentrations of hormones were determined in separate animals from those used for the injection of labelled hormone.

\section{Rate of utilization of $T_{4}$}

The rate of utilization of $T_{4}$ was estimated as previously described (Evans \& Ingram, 1977; Ingram \& Kaciuba-Uscilko, I977). Thyroxine labelled with ${ }^{125}$ ( (The Radiochemical Centre, Amersham, Bucks.) was injected in a dose of $25 \mu \mathrm{Ci}$. Samples were then taken every $3^{-12} \mathrm{~h}$ for $70 \mathrm{~h}$ beginning $12 \mathrm{~h}$ after the injection. The radioactive content was expressed as the percentage of the dose initially injected/1 plasma. The dose administered was calculated from the ${ }^{125}$ I estimated in a $1: 999$ dilution of the solution injected. As in previous studies the labelled hormone was washed out of the catheter by repeated withdrawal and reinjection of blood.

\section{Analysis of results}

The fractional disappearance rate constant $k$ was calculated using a single exponential decay model:

$$
y=b e^{-k x},
$$

where $y$ is the $\%$ dose of ${ }^{125} \mathrm{I} / \mathrm{ml}$ plasma, $x$ is the time after injection (h), $b$ is the range of $\%$ dose ${ }^{125}$ I as time passes from zero to infinity, $k$ is the ${ }^{125} \mathrm{I}$ disappearance rate constant. One value of $k$ was thus obtained from each curve. 


\section{Estimation of serum $T_{3}$ and $T_{4}$}

The plasma was separated by centrifugation and the samples stored at $-20^{\circ}$ before being dispatched to the hospital laboratory for analysis. The concentration of $T_{4}$ was determined using a radioimmunoassay technique previously described (Evans et al. I977). Values were compatible with values previously obtained using competitive binding assays (Evans \& Ingram 1974, 1977). Serum $T_{3}$ concentration was determined using a solid phase radioimmunoassay technique (Immophase, Corning Medical, Halstead, Essex).

All assays were carried out in duplicate and subjected to routine quality-control procedures and variation between assays was indicated by $95 \%$ confidence limits of $6 \%$ for $\mathrm{T}_{4}$ and $9 \%$ for $T_{3}$. In any instance where a value was believed to be abnormally high or low a second analysis was made.

\section{Experimental procedure}

All pigs were kept at the Institute of Animal Physiology, Babraham, on a diet of standard pig, meal fed at a quantity equivalent to $20 \mathrm{~g} / \mathrm{kg}$ body-weight for I week before the experiments started. The order in which different diets were presented was varied between pigs. In the determination of $k$ the pigs were fed the given diet for $5 \mathrm{~d}$ before injection of ${ }^{125}$ I thyroxine and the diet continued while $k$ was being determined.

\section{RESULTS}

The rate of utilization of $T_{4}$

Four groups of pigs all received $20 \mathrm{~g}$ pig meal $/ \mathrm{kg}$ body-weight for I week and $40 \mathrm{~g} / \mathrm{kg}$ bodyweight in a second week. In a third week each group received a different supplement of bran, fish meal, glucose, or desiccated coconut in addition to $20 \mathrm{~g} \mathrm{pig} \mathrm{meal} / \mathrm{kg}$ body-weight. The supplement of bran was equivalent in bulk to $20 \mathrm{~g} \mathrm{pig} \mathrm{meal} / \mathrm{kg}$ body-weight. The remaining supplements were equivalent in energy content to $20 \mathrm{~g} \mathrm{pig} \mathrm{meal} / \mathrm{kg}$ body-weight. The results are given in Table 2.

Effect of energy intake. The effect of changing the energy intake from 20 to $40 \mathrm{~g} / \mathrm{kg}$ bodyweight can be evaluated from the results obtained on thirty-one pigs. The mean value for $k$, which indicates the rate of utilization, was 0.0296 and 0.0339 for 20 and $40 \mathrm{~g} / \mathrm{kg}$ bodyweight respectively. A paired $t$ test indicated that there was a statistically-significant difference between these values $(P<0.00 \mathrm{I})$.

Effect of nutrient composition. Comparisons between $40 \mathrm{~g} / \mathrm{kg}$ body-weight and $20 \mathrm{~g} / \mathrm{kg}$ body-weight plus glucose, fish meal or coconut were also made by paired $t$ tests. There was no significant difference $(P>0.05)$ in the value of $k$ for $40 \mathrm{~g} / \mathrm{kg}$ body-weight and $20 \mathrm{~g} / \mathrm{kg}$ body-weight plus coconut (high-fat) or $20 \mathrm{~g} / \mathrm{kg}$ body-weight plus fish meal (high-protein). The rate of utilization was however significantly greater $(P<0.02)$ on $40 \mathrm{~g}$ pig meal $/ \mathrm{kg}$ body-weight than on $20 \mathrm{~g} / \mathrm{kg}$ body-weight plus glucose. On the other hand the values of $k$ for $20 \mathrm{~g} / \mathrm{kg}$ body-weight alone and supplemented with glucose were not different $(P>0.05)$; while there were significant differences between $20 \mathrm{~g}$ pig meal $/ \mathrm{kg}$ body-weight alone and supplemented with coconut or fish meal $(P<0.02)$.

Effect of bulk of food. The effect of changing the bulk of the food but not its energy content could be determined from the study using a supplement of bran. The value of $k$ was not significantly different $(P>0.05)$ between $20 \mathrm{~g}$ pig meal $/ \mathrm{kg}$ alone and $20 \mathrm{~g} \mathrm{pig} \mathrm{meal} / \mathrm{kg}$ supplemented with bran; but it was different between $40 \mathrm{~g} \mathrm{pig} \mathrm{meal} / \mathrm{kg}$ and $20 \mathrm{~g} \mathrm{pig} \mathrm{meal} / \mathrm{kg}$ plus bran $(P<0.02)$ indicating that the bulk of food did not change the value of $k$. 
Table 2. Values of rate of utilization for thyroxine for pigs given different diets*

(Mean values with their standard errors; no. of pigs in parentheses)

\begin{tabular}{|c|c|c|c|c|c|c|}
\hline \multirow{2}{*}{$\begin{array}{c}\text { Dietary supplement } \\
\text { Diet }(\mathrm{g} / \mathrm{kg} \text { body -weight })\end{array}$} & \multicolumn{2}{|c|}{$\begin{array}{c}20 \\
+ \text { supplement }\end{array}$} & \multicolumn{2}{|c|}{20} & \multicolumn{2}{|c|}{40} \\
\hline & Mean & SEM & Mean & SEM & Mean & SEM \\
\hline Bran (9) & 0.0305 & 0.0014 & 0.0321 & 0.0009 & 0.0338 & 0.0009 \\
\hline Fish meal (8) & 0.0349 & 0.0012 & 0.0312 & 0.0014 & 0.0362 & 0.0013 \\
\hline Coconut (7) & 0.0369 & 0.0027 & 0.0262 & 0.0004 & 0.0338 & 0.0027 \\
\hline Glucose (7) & $0.027 I$ & 0.0011 & 0.0282 & 0.0013 & $0.036 \mathrm{I}$ & 0.0042 \\
\hline
\end{tabular}

\section{Concentrations of $T_{3}$ and $T_{4}$ in plasma}

The day to day variations in the concentrations of $T_{4}$ in plasma were sometimes as great as Io $\mathrm{nmol} / \mathrm{l}$. The mean values for individual animals also varied and for this reason comparisons of $T_{3}$ and $T_{4}$ concentrations were restricted to those within individuals using paired $t$ tests. Variations in $T_{3}$ concentration were smaller than for $T_{4}$ but inspection of the records suggested that a rise or fall in $T_{4}$ was accompanied by a corresponding change in $T_{3}$ and this was confirmed by a statistically-significant correlation coefficient $(P<0.01)$.

Time of feeding. The possible effects of taking blood samples before or after a meal were investigated in two sets of pigs all fed at the same time of day. Four pigs were fed at $30 \mathrm{~g} / \mathrm{kg}$ body-weight as pig meal once daily for I week and $60 \mathrm{~g} / \mathrm{kg}$ body-weight for the next week. Another four pigs were given 10 and $40 \mathrm{~g} / \mathrm{kg}$ body-weight in successive weeks. Blood samples were taken over the last $5 \mathrm{~d}$ of each diet, one sample just before feeding and the next sample $2 \mathrm{~h}$ later. The differences in serum concentrations of $T_{3}$ and $T_{4}$ displayed no consistent trends and no statistically-significant differences were found (Fig. I).

Energy intake. The effect of energy intake on values of serum $T_{3}$ and $T_{4}$ were determined in two experiments using standard pig meal. In the first experiment fourteen pigs were given $20 \mathrm{~g} / \mathrm{kg}$ body-weight per $\mathrm{d}$ for I week and then $40 \mathrm{~g} / \mathrm{kg}$ for the next week. The values for each hormone were then determined from the mean values for each pig over the last $5 \mathrm{~d}$. This provided a comparison between the lowest intake which would just allow growth and an intake which allowed moderate growth at a rate typical of husbandry conditions. In the second experiment seven pigs were fed at $15 \mathrm{~g} / \mathrm{kg}$ body-weight, which was just enough to prevent loss of weight for $\mathrm{I}$ week, and then food was withheld for $5 \mathrm{~d}$. Hormone levels were obtained from the values over the last $5 \mathrm{~d}$ on $15 \mathrm{~g} / \mathrm{kg}$ body-weight and over the entire $5 \mathrm{~d}$ in which food was withheld. The results of both experiments are shown in Table 3. Paired $t$ tests within individual pigs revealed no differences in hormone levels between food intakes at 20 and $40 \mathrm{~g} / \mathrm{kg}$ body-weight, but similar tests between intakes of $\mathrm{I} 5$ and $\mathrm{og} / \mathrm{kg}$ body-weight of food were statistically significant for both $\mathrm{T}_{3}$ and $\mathrm{T}_{4}(P<0.00 \mathrm{I}$, and $P=0.02-0.0 \mathrm{I}$ respectively). As can be seen the values for 15,20 and $40 \mathrm{~g} / \mathrm{kg}$ body-weight for particular hormones were all similar.

Composition of the diet. The possible effects of the composition of the diet on the values of $T_{3}$ and $T_{4}$ were investigated in a series of studies using four different groups of five or six pigs for each diet. The animals were given $20 \mathrm{~g}$ pig meal $/ \mathrm{kg}$ body-weight plus the various supplements and the values for $T_{3}$ and $T_{4}$ were again determined over the last $5 \mathrm{~d}$. As in the previous experiments the supplement which consisted of the energy equivalent to $20 \mathrm{~g} / \mathrm{kg}$ body-weight was given as fish meal (high-protein), desiccated coconut (high-fat) or glucose. In addition one group received a supplement of bran which was equivalent in bulk to $20 \mathrm{~g}$ pig meal $/ \mathrm{kg}$ body-weight. The results which are given in Table 4 were subjected to the 


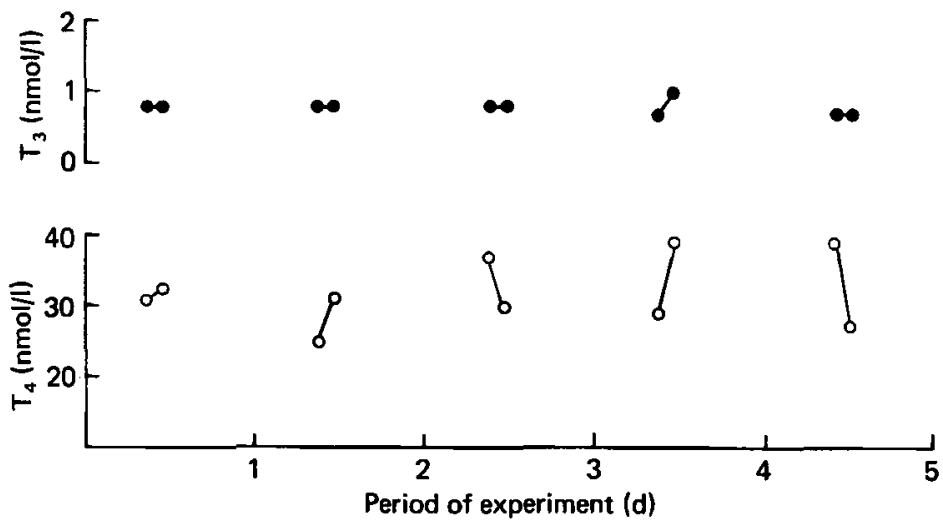

Fig. I. Serum concentrations of thyroid hormones $\left(T_{4}\right.$ and $\left.T_{8} ; n m o l / l\right)$ in samples of blood taken just before feeding and $2 \mathrm{~h}$ later over a $5 \mathrm{~d}$ period. Results from a single pig given $40 \mathrm{~g} / \mathrm{kg}$ bodyweight. (For details, see p. 528 and Table 1 .)

Table 3. Effect of energy intake given as pig meal* on values of plasma thyroid hormones $\left(\mathrm{T}_{3}\right.$ and $\left.T_{4}\right)$

(Mean values with their standard errors; in Expt 1 the pigs were growing, in Expt 2 they were not; no. of pigs in parentheses)

Food intake

Expt no.

I (I4)

$2(7)$ (g/kg body-weight)

20
40
15
0

Hormone concentrations ( $\mathrm{nmol} / \mathrm{l})$

$\overbrace{\text { Mean }}^{\text {TEM }} \begin{array}{cc}1.7 & 0.19 \\ 1.9 & 0.18 \\ 1.3 & 0.12 \\ 0.7 & 0.11\end{array}$

$\overbrace{\text { Mean }}^{\text {SEM }} \begin{array}{rr}37 \cdot 1 & 1.9 \\ 35 \cdot 1 & 1.9 \\ 37 \cdot 7 & 15.6 \\ 22 \cdot 3 & 4.2\end{array}$

Table 4. Plasma thyroid hormones $\left(T_{3}\right.$ and $\left.T_{4}\right)$ concentrations (nmol/l) in pigs given $20 \mathrm{~g}$ pig meal $/ \mathrm{kg}$ body-weight per $d$ supplemented with glucose, coconut or fish meal*

(Mean values with their standard errors. The diets had the same energy content as a diet of $40 \mathrm{~g}$ pig meal $/ \mathrm{kg}$ body-weight, the diet supplement with bran had the same bulk as the $40 \mathrm{~g} / \mathrm{kg}$ bodyweight and the same energy content as $20 \mathrm{~g} \mathrm{pig}$ meal $/ \mathrm{kg}$ body-weight)

\begin{tabular}{|c|c|c|c|c|c|c|}
\hline \multirow[t]{2}{*}{ Supplement... } & \multicolumn{2}{|c|}{ Bran } & Fish meal & Coconut & \multicolumn{2}{|c|}{ Glucose } \\
\hline & Mean & SEM & Mean SEM & Mean SEM & Mean & SEM \\
\hline$T_{3}$ & $\begin{array}{l}1 \cdot 30 \\
30 \cdot 3\end{array}$ & 0.15 & $\begin{array}{ll}0.67 & 0.06\end{array}$ & $\begin{array}{ll}I \cdot 14 & 0.05 \\
38.8 & I .7\end{array}$ & $\begin{array}{l}2 \cdot 30 \\
38 \cdot 5\end{array}$ & 0.18 \\
\hline
\end{tabular}

analysis of variance which revealed a statistically-significant effect for both $T_{3}$ and $T_{4}$ ( $P<0.001$ and $P<0.01-0.001$ respectively). The value for $\mathrm{T}_{3}$ was significantly lower for the diet containing fish meal than for glucose. The concentration of $T_{4}$ was significantly lower on the diet containing bran than on fish meal. 


\section{DISCUSSION}

Rats which are exposed to cold and allowed to eat more food have an increased loss of $T_{4}$ in the faeces (Van Middlesworth, 1960). Changes in diet have in fact been shown to have a greater effect on faecal excretion of $T_{4}$ than cold alone (Hillier, I968; Straw, 1969). Increased faecal loss of $T_{4}$ appears to be related to a greater enterohepatic circulation of thyroxine (Cottle \& Veress, I 966 ) and it has been suggested that the increased faecal bulk augments the loss of $T_{4}$ in the faeces and so causes an increased rate of turnover of the hormone. In the present study the increased value of $k$ when food intake increased from 20 to $40 \mathrm{~g} / \mathrm{kg}$ body-weight might have been due to the excretion of $T_{4}$ in the faeces. This was unlikely to have been the situation since when the pigs were given bran, which is not digested, the bulk of faeces would have been increased more than when changing from 20 to $40 \mathrm{~g}$ pig meal $/ \mathrm{kg}$ body-weight; while the value of $k$ did not alter. A similar result was obtained previously (Ingram \& Kaciuba-Uscilko, 1977) when the bulk of the diet was increased with chopped straw. The diet containing straw was not, however, readily eaten and it was possible that the unappetizing food could have influenced the secretion or metabolism of $T_{4}$. By contrast the bran was eaten much more readily. For these reasons the differences in the value of $k$ on diets of $20 \mathrm{~g} \mathrm{pig} \mathrm{meal} / \mathrm{kg}$ body-weight plus a supplement seem unlikely to have been related to faecal bulk even though there was a marked difference in the amount of dietary fibre in, for example, the diets containing desiccated coconut, or glucose. Moreover, in rats which have been exposed to the cold it has also been shown that the high secretion rate of $T_{4}$ is independent of the bulk of the diet (Heroux \& Petrovic, 1969). The pigs given a supplement of bran did have a low value for plasma $T_{4}$ which may have been related to faecal loss of hormone.

The effects of dietary composition on metabolic rate between 12 and $20 \mathrm{~h}$ after feeding have been studied by Dauncey \& Ingram (1979). The changes they found in metabolic rate correspond closely to the changes in the rate of utilization of $T_{4}$ observed in the present study. Increasing the energy intake as pig meal, coconut or fish meal resulted in an increase in metabolic rate during the whole $8 \mathrm{~h}$ period, but when the extra energy was supplied as glucose the metabolic rate was unchanged. It appears therefore that specific nutrients can influence both the rate of utilization of $T_{4}$ and the resting metabolic rate. The studies from which this conclusion was reached did however involve diets in which particular nutrients accounted for a large proportion of the total energy intake. In a more balanced diet the effects of specific nutrients would probably be less obvious.

There are two explanations for the changes in the rate of utilization of $T_{4}$. One is that the production of $T_{4}$ is stimulated by some constituents in food either directly or indirectly and this increases metabolic rate. If this was the situation then it would follow that glucose is not a sufficient stimulant and that utilization of $T_{4}$ parallels its secretion. Another possibility is that there is an increased use of $T_{4}$ caused by the processing of complex foods which is itself sufficient to initiate and maintain a high rate of metabolism. In this event the increased consumption of $T_{4}$ would lead to an increased rate of secretion through the normal feedback control, and so the value of $k$ would rise. The fish meal may have contained thyroid hormones and TSH and these would have exerted a separate effect from that related to the energy content of the diet. It would appear, however, that even if these hormones were present in the fish meal the effect that they had on the utilization of $T_{4}$ was small since the value of $k$ was similar for $60 \mathrm{~g}$ pig meal $/ \mathrm{kg}$ body-weight and for the diet of $20 \mathrm{~g}$ pig meal $/ \mathrm{kg}$ body-weight plus the supplement of fish meal. The slightly higher values for plasma $T_{4}$ after fish meal may on the other hand have been related to ingested hormone.

If the increased turnover of $T_{4}$ stems from an increased metabolic rate then initially it would be expected that the $T_{4}$ levels would decline. In the present study $T_{4}$ was estimated only after the change of diet had been established for $2 \mathrm{~d}$ and so a fall would not in any event 
have been seen. Statistically-significant changes in the concentration of thyroid hormones were seen when food was with held completely. The fall in $T_{3}$ has been observed in man where it was associated with a rise in reverse $T_{3}$, but in these studies the levels of $T_{4}$ declined only slightly and in some cases did not change (Portnay et al. 1974; Chopra \& Smith, 1975; Vagenakis et al. 1975; Palmblad et al. 1977). The fact that the plasma level of $\mathrm{T}_{4}$ declined when food was withheld is pertinent to the present discussion since it indicates that a simple fall in $T_{4}$ is not sufficient to increase the rate of secretion. In fact it tends to support the usual view that metabolic rate is determined by $T_{4}$ level, rather that the utilization rate of $T_{4}$ being determined by the metabolic rate. The effect of dietary supplements on serum $T_{3}$ needs further investigation involving measurements of reverse $T_{3}$. It may however be of significance that the lowest value for $T_{3}$ was associated with the most rapid rate of utilization of $\mathrm{T}_{4}$ and the highest value with the lowest rate.

The authors thank Mr D. Brown, ARC Statistics Unit for his help and the analyses of the results and $\mathrm{Mr} \mathrm{K}$. F. Legge for his skilled assistance.

\section{REFERENCES}

Chopra, I. J. \& Smith, S. R. (1975). J. clin. Endocr. Metab. 40, 221.

Cottle, W. H. \& Veress, A. T. (1966). Can. J. Physiol. Pharmac. 44, 571.

Dauncey, M. J. \& Ingram, D. L. (I979). Br. J. Nutr. 41, 36I.

Evans, S. E., Burr, W. A. \& Hogan, T. C. (1977). Annls. clin. Biochem. 14, 330.

Evans, S. E. \& Ingram, D. L. (1974). J. Physiol., Lond. 236, 159.

Evans, S. E. \& Ingram, D. L. (1977). J. Physiol., Lond. 264, 5 I I.

Freinkel, J. \& Lewis, D. (1957). J. Physiol., Lond. 135, 288.

Heroux, O. \& Petrovic, V. M. (I969). Can. J. Physiol. Pharmac. 47, 963.

Hershman, J. M., Read, D. G., Bailey, A. L., Norman, V. D. \& Gibson, T. B. (1970). J. clin. Endocr. 30, 430.

Hillier, A. P. (1968). J. Physiol, Lond. 197, 123.

Ingram, D. L. \& Dauncey. M. J. (1980). Proc. 8th Symp. Energy Metab. (In the Press).

Ingram, D. L. \& Kaciuba-Uscilko, H. (1977). J. Physiol., Lond. 270, 431.

Palmblad, J., Levi, L., Burger, A., Melander, A., Westgren, U., Schneck, H. von \& Skude, G. (1977). Acta Med. scand. 2or, 15.

Paul, A. A. \& Southgate, D. A. T. (1978). McCance \& Widdowson's The Composition of Foods, 4 th ed. London: HM Stationery Office.

Portnay, G. I., O'Brian J. T., Bush, J., Vagenakis, A. G., Azizi, F., Arky, R. A., Ingbar, S. A. \& Braverman, L. E. (1974). J. clin. Endocr. Metab. 39, I 91.

Reichlin, S. (1966). In Neuroendocrinology, vol. 1, p. 295. [L. Martini \& W. F. Ganong, editors]. New York and London: Academic Press.

Reichlin, S., Martin, J. B., Mitnich, M. A., Boshans, R. L., Grimm, Y., Bollinger, J., Gordon, J. \& Malacara, J. (1972). Rec. Prog. Horm. Res. 28, 229.

Straw, J. A. (1969). J. appl. Physiol. 27, 630.

Vagenakis, A. G., Burger, A., Portnay, G. I., Rudolph, M., O'Brian, J. T., Azizi, F., Arky, R. A., Nicod, P., Ingbar, S. H. \& Braverman, L. E. (1975). J. clin. Endocr. Metab. 41, I91.

Van Middlesworth, L. (1960). Rec. Prog. Horm. Res. 16, 405. 